\title{
Penegakan Supremasi Hukum Melalui Implementasi Nilai Demokrasi
}

\author{
Soesi Idayanti ${ }^{1}$, Toni Haryadi², Tiyas Vika Widyastuti ${ }^{3}$ \\ Universitas Pancasakti Tegal \\ Jalan Halmahera KM 1 Mintaragen Tegal \\ Soesi.idayanti@gmail.com, toniharyadi54@gmail.com tiyasvikawidyastuti@gmail.com \\ Masuk: 2 Mei 2020; Diterima: 27 Mei 2020; Terbit: 29 Mei 2020.
}

DOI : $10.24905 /$ diktum.v8i1.85

\begin{abstract}
The purpose of research to know the post-reform law enforcement in establishing a harmonious, fairness and berkepastian life in an orderly society is not in accordance with the fact that the Reformation mandate in law enforcement turned out to be very grievous. Law enforcement that is "cutting select" is inevitable, although the cause is not a political factor as in the previous era. The problems raised in this study were how the direction of legal development and how to enforce the supremacy of law based on the values of democracy. The results of the research showed that the supremacy of the law as an effort to law enforcement and the placement of law in the highest position of everything, as well as making the law as commander or commander in an effort to safeguard and protect the level of stability in the life of a nation and the nation gives assurance of justice to society. Fairness should be positioned neutrally, meaning that everyone has the same position and treatment without exception. The supremacy of the law is an absolute prerequisite for the implementation of the country based on people's sovereignty. The main objective of the supremacy of the law is to make the law as a leader in living the nation's life and state, which if the goal is achieved can produce some things such as improving the integrity of human resources, providing social justice, maintaining the moral value of the nation, creating a democratic society, and providing assurance of protection of individuals in state and community
\end{abstract}

Keywords: Enforcement of law supremacy, implementation, values of democracy 


\begin{abstract}
Abstrak
Tujuan penelitian untuk mengetahui Penegakan hukum pasca reformasi dalam membangun kehidupan yang harmonis, berkeadilan dan berkepastian dalam masyarakat yang tertib ternyata tidak sesuai dengan kenyataan bahwa amanat reformasi dalam penegakan hukum ternyata menjadi sangat memilukan. Penegakan hukum yang bersifat " tebang pilih " tak terhindarkan, meski penyebabnya bukanlah faktor politis seperti pada era sebelumnya. Permasalahan yang diangkat dalam penelitian ini adalah bagaimana arah pembangunan hukum dan bagaimana menegakan supremasi hukum berdasarkan nilai - nilai demokrasi. Hasil penelitian menunjukan bahwasanya Supremasi hukum sebagai upaya penegakan hukum dan penempatan hukum pada posisi tertinggi dari segalanya, serta menjadikan hukum sebagai panglima ataupun komandan dalam upaya untuk menjaga dan melindungi tingkat stabilitas dalam kehidupan suatu bangsa dan negara memberikan jaminan terciptanya keadilan bagi masyarakat. Keadilan harus diposisikan secara netral, artinya setiap orang memiliki kedudukan dan perlakuan yang sama tanpa terkecuali. Supremasi hukum merupakan prasyarat mutlak bagi penyelenggaraan kehidupan bernegara berdasarkan kedaulatan rakyat. Tujuan utama adanya supremasi hukum adalah menjadikan hukum sebagai pimpinan dalam menjalankan kehidupan berbangsa dan bernegara, yang mana apabila tujuan tersebut tercapai dapat menghasilkan beberapa hal seperti meningkatkan integritas sumber daya manusia, memberikan keadilan sosial, menjaga nilai moral bangsa, menciptakan masyarakat yang demokratis, serta memberi jaminan perlindungan hak individu dalam bernegara dan bermasyarakat
\end{abstract}

Kata Kunci : Penegakan Hukum, Supremasi Hukum, Implementasi, Nilai Demokrasi

\title{
A. Pendahuluan
}

Proklamasi Kemerdekaan dan pembentukan Negara Republik Indonesia yang dituangkan dalam Undang-Undang Dasar 1945 membawa perubahan besar dalam semua aspek kehidupan kemasyarakatan di wilayah Indonesia Perubahan ini termasuk pada penyelenggaraan hukumnya. Dengan itu secara implisit sudah terjadi perubahan dalam isi cita hukum sebagai asas yang mempedomani dalam penyelenggaraan hukum di Indonesia. Dalam Pemerintahan berdasarkan atas hukum karakter produk hukum sangat ditentukan oleh konfigurasi politik yang melahirkannya .

Orde lama telah memanipulasi hukum untuk kepentingan politik. Hukum menjadi hukumnya penguasa, yaitu penguasa tunggal yang mengatasnamakan dirinya sebagai mandataris MPR yang menjadikan hukum telah kehilangan dimensi etisnya ${ }^{1}$. Fakta kehidupan hokum tersebut mendorong pemikiran untuk

\footnotetext{
${ }^{1}$ Koento Wibisono Siswomihardjo, Wajah Hukum di Era Reformasi, Menyambut 70 Tahun Satjipto Rahardjo, Bandung: Citra Aditya Bakti, 2000. hlm 149.
} 
mencari dan merencanakan sebuah alternative strategi pembangunan hukum yang lebih akrab dengan cita rasa keadilan.

Model strategi pembangunan hukum dalam suatu masyarakat untuk sebagian besar merupakan hasil proses politik. Namun hal itu bukan berarti tertutup kemungkinan untuk memikirkan, mencari, merencanakan dan menerapkan suatu strategi lain yang lebih dekat dengan kepentingan rakyat banyak. Diperlukan suatu strategi pembangunan hukum responsip-progresip sebagai cara untuk mendorong dan mempercepat memproses "emansipasi sosial" masyarakat. Konsep ini mengisyaratkan perlunya diciptakan kondisi tertentu yang dapat memberikan kesempatan kepada masyarakat mengorganisasikan kepentingan mereka.

Ada beberapa hal yang harus dimiliki oleh suatu negara untuk dapat dikatakan sebagai negara hukum, yaitu dimana negara tersebut harus menjadikan superioritas hukum sebagai aturan main dalam negara tersebut. Soetandyo Wignjosoebroto memberikan pendapat tentang pengertian supremasi hukum, menurut pandangan beliau supremasi hukum dapat diartikan sebagai upaya dalam penegakan hukum dan penempatan hukum sebagai posisi tertinggi dalam suatu negara yang dapat digunakan untuk melindungi semua lapisan masyarakat tanpa intervensi atau gangguan dari pihak manapun termasuk pihak penyelenggara negara ${ }^{2}$. Menambahkan pendapat Soetandyo, menurut Abdul Manan, hukum adalah sebagai panglima ataupun komandan dalam upaya untuk menjaga dan melindungi tingkat stabilitas dalam kehidupan suatu bangsa dan negara. Tujuan utama adanya supremasi hukum adalah menjadikan hukum sebagai pimpinan dalam menjalankan kehidupan berbangsa dan bernegara, yang mana apabila tujuan tersebut tercapai dapat menghasilkan beberapa hal seperti meningkatkan integritas sumber daya manusia, memberikan keadilan sosial,

\footnotetext{
${ }^{2}$ Soetandyo Wignyosoebroto, Hukum Paradigma, Metode dan Dinamika Masalahnya, Jakarta: Huma. 2002, hlm 164.
} 
menjaga nilai moral bangsa, menciptakan masyarakat yang demokratis, serta memberi jaminan perlindungan hak individu dalam bernegara dan bermasyarakat.

\section{B. Rumusan Masalah}

1. Bagaimana arah pembangunan hukum menuju terwujudnya supremasi hukum?

2. Bagaimana penegakan supremasi hukum melalui implementasi nilai-nilai demokrasi?

\section{Pembahasan}

\section{Arah Pembangunan Hukum Menuju Terwujudnya Supremasi Hukum}

Reformasi konstitusi telah menegaskan secara eksplisit bahwa Indonesia adalah negara hukum. Pasal 1 ayat (3) Undang-Undang Dasar Negara Republik Indonesia Tahun 1945 menyatakan : "Negara Indonesia adalah negara hukum " Ketentuan tersebut mengandung makna antara lain bahwa adanya pengakuan terhadap prinsip supremasi hukum dan konstitusi, adanya prinsip peradilan yang bebas dan tidak memihak yang menjamin persamaan setiap warga negara dalam hukum, serta jaminan keadilan bagi setiap orang termasuk terhadap penyalahgunaan wewenang oleh pihak yang berkuasa. Artinya dengan hukum yang benar-benar supreme diharapkan akan melahirkan ketertiban atau tata kehidupan yang harmonis dan keadilan bagi masyarakat, dengan demikian pada gilirannya hukum dapat berperan dalam menjaga stabilitas bagi seluruh negara.

Penegakan hukum pasca reformasi dalam membangun kehidupan yang harmonis, berkeadilan dan berkepastian dalam masyarakat yang tertib ternyata tidak sesuai dengan kenyataan bahwa amanat reformasi dalam penegakan hukum ternyata menjadi sangat memilukan. Penegakan hukum yang bersifat " tebang pilih " tak terhindarkan, meski penyebabnya bukanlah faktor politis seperti pada era sebelumnya.

Penegakan hukum tanpa tebang pilih terhadap banyaknya kasus yang terjadi di negara kita, contohnya kasus korupsi dimana terhadap para koruptor 
karena perbuatan mereka telah banyak menyengsarakan rakyat menjadi indikator untuk menuntut kepada pemerintah dalam melakukan tindakan yang bersifat non diskriminatif dalam penegakan supremasi hukum. Problem penegakan hukum selama ini disebabkan oleh beberapa hal diantaranya faktor persoalan politik dan persoalan paradigmatik. Persoalan politik adalah warisan birokrasi yang korup dan rekuitmen politik yang keliru. Sedangkan persoalan paradigmatik adalah ambiguitas orientasi atas konsepsi negara hukum.

Solusi politik untuk memutuskan kasus-kasus Korupsi dan kasus-kasus yang lain adalah dengan secara tegas memutus hubungan kasus-kasus peninggalan rezim terdahulu dilakukan dengan cara diantaranya : ${ }^{3}$

Pertama, melakukan amputasi ( pemberhentian masal) atas pejabat-pejabat birokrasi terutama birokrasi penegak hukum, yang berada pada usia dan level tertentu, melalui undang-undang lustrasi agar tindakan hukum dapat dilakukan secara tegas dan lugas

Kedua, melakukan pemutihan dengan memberikan pengampunan secara nasional (national pardon) atas para pelaku pelanggaran dimasa lalu, dengan alasan bahwa sangat sulit melakukan penyelesaian secara tegas berdasarkan hukum atas kasus yang begitu banyak dan rumit dan yang dilakukan oleh mereka sebagai akibat adanya system yang memaksa ketika itu.

Ketiga, perlu ada pergeseran orientasi atas konsepsi negara hukum dari rechsstaat menjadi the rule of law seperti negara-negara Anglo Saxon. Dengan paradigm ini maka setiap upaya penegakan hukum akan mampu melepaskan diri dari jebakan-jebakan formalitas-prosedural serta mendorong para penegak hukum untuk kreatif dan berani menggali nilai-nilai keadilan serta menegakan etika dan moral didalam masyarakat dalam setiap peenyelesaian kasus hukum.

\footnotetext{
${ }^{3}$ hhtp:/mahfudmd.com./index.php.page.web.beritaDetail\&id.diakses tgl 12 desember 2019
} 
Masyarakat Indonesia belum memberikan perhatian sungguh-sungguh terhadap stabilitas, padahal pembangunan dinegara penganut system demokrasi apapun memerlukan stabilitas nasional yang baik. Apa konsekuensinya jika banyak orang sudah tidak percaya lagi kepada hukum dan fungsi untuk merekayasa perubahan sosial ? Dalam konteks keadaan seperti ini ada beberapa hal yang dapat dilakukan untuk menyelamatkan situasi kehidupan hukum kita yang kurang nyaman bagi masyarakat lapisan bawah yaitu ${ }^{4}$ :

Pertama, perlu diciptakan kondisi sosial yang memungkinkan pertumbuhan sejati kelompok kolektif masyarakat lapis bawah yang benar-benar dapat berfungsi untuk mengorganisasikan dan memperjuangkan hak-hak dan kepentingan mereka

Kedua, memperbesar akses masyarakat, khususnya masyarakat lapis bawah dan menegah di lembaga pengadilan harus mendapatkan perlakuan yang adil dari pihak pengadilan.Dengan demikian idealnya para hakim memiliki keberaniana untuk menghasilkan yurisprudensi progresif yang benar-benar tanggap terhadap tuntutan kebutuhan masyarakat luas, khususnya bagi masyarakat lapis bawah.

Ketiga, organisasi sosial non pemerintah yang selama ini bergerak di bidang penyadaran masyarakat dana bantuan hukum seperti Lembaga Bantuan Hukum (LBH), kelompok penyedar kelestarian lingkungan, lembaga konsumen dan sebagainya harus meningkatkan perannya untuk menyadarkan hak-hak masyarakat lapis bawah, bersamaan dengan itu merencanakan program-program litigasi baru yang diarahkan untuk

\footnotetext{
${ }^{4}$ Abdul Hakim G Nusantara, Kebijakan dan Strategi Pembangunan Hukum di Indonesia, Sebuah Tinjauan Kritis politik Pembinaan Hukum Indonesia, dalam buku Pembangunan Hukum dalam Perspektif Politik Hukum Nasional, Jakarta: CV Rajawali, 2000. hlm 165.
} 
merangsang tumbuhnya yurisprudensi -yurisprudensi baru yang responsifeprogresif.

Keempat, menyadari keterbatasan lembaga peradilan, organisasi sosial non pemerintah bersama dengan pemerintahah menstimulir masyarakat, khususnya lapisan masyarakat terbawah, agar lembaga abritase dapat berfungsi dalam menjembatani kepentingan masyarakat dengan birokrasi pemerintah.

Kelima, diadakan penelitian yang khusus mempelajari, manganalisis, dan memberikan caatatan, dari segi formal maupun dibidang penalaran keputusan para hakim dalam menghadapi kasus yang pernah maupun yang sedang dihadapi di pengadilan.

Dalam proses pembangunan hukum, pemerintah mengakui masih banyaknya permasalahan dibidang hukum yang belum bisa teratasi. Dibidang kelembagaan hukum misalnya , masih terdapat permasalahan diantaranya ${ }^{5}$ :

(a) Kurangnya independensi kelembagaan hukum, terutama lembagalembaga penegak hukum membawa akibat terabaikannya prinsip impartialitas dalam banyak putusan lembaga yudikatif. Hal ini akan berperan terhadap terjadinya degradasi kepercayaan masyarakat kepada sistem hukum maupun goyahnya kepastian hukum.

(b) Independensi lembaga hukum harus disertai dengan akutabilitas, namun demikian dalam prakteknya pengaturan tentang akutabilitas lembaga hukum tidak dilakukan dengan jelas, baik kepada siapa atau lembaga mana ia harus bertanggung jawab maupun tata cara bagaimana yang harus dilakukan untuk memberikan kesan tiadanya transparansi didalam proses penegakan hukum

${ }^{5}$ Wicipto Setiadi, Pembangunan Hukum Dalam Rangka Meningkatkan Supremasi Hukum, Jurnal RechtsVinding, Volume 1 Nomor 1, April 2012. hlm 36. 
(c) Sinyalemen tentang kurangnya integritas dari para penyelenggara negara juga sangat memprihatinkan. Kasus-kasus hukum yang sedang berlangsung diberbagai lembaga negara, berpengaruh besar terhadap memudarnya supremasi hukum serta semakin berdampak pada ketidakpercayaan masyarakat terhadap sistem hukum yang ada.

\section{Penegakan supremasi hukum melalui implementasi nilai-nilai demokrasi}

Strategi pembangunan hukum responsif-progresif yang meletakan peranan kolektif kelompok masyarakat, khususnya masyarakat lapis bawah beserta lembaganya dalam proses pembentukan hukum berada dalam posisi yang menentukan. Melalui partisipasi masyarakat, diharapkan gerakan emansipasi sosial dapat mewujudkan keadilan sosial masyarakat. Pada prinsipnya kerangka utama politik pembangunan hukum nasional sebagai sarana untuk mencapai tujuan negara harus berpijak pada (a) cita-cita bangsa yaitu masyarakat adil dan makmur, harus dipadu dengan nilai-nilai Pancasila sebagai dasar negara yaitu berbasis moral agama, menghargai dan melindungi hak-hak asasi manusia tanpa diskriminasi, (b) mempersatukan seluruh bangsa, meletakan kekuasaan dibawah kekuasaan rakyat, dan membangun keadilan sosial. (c) harus melindungi semua unsur bangsa demi integrase atau keutuhana bangsa, mewujudkan keadilan sosial dalam ekonomi dan kemasyarakatan, mewujudkan demokrasi ( kedaulatan rakyat )

Sejauh ketentuan peraturan perundang-undangan dilaksanakan sesuai menurut isi undang-undang, akan selalu memenuhi kepentingan umum. Sebab dalam negara Republik dimana "res publica" berarti negara yang kedaulatannya adalah milik rakyat, oleh rakyat dan untuk rakyat, maka ketertiban ini merupakan tujuan untuk keputusan seluruh warga masyarakatnya. Oleh karena itu koreksi mendasar dalam reformasi yang dipelopori mahasiswa itu, harus ditindak lanjuti dengan agenda utama yaitu mengubah wajah hukum yang totalitarian menjadi hokum yang berpihak pada 
'DIKTUM: JURNAL ILMU HUKUM

ISSN: 2655-3449 (E) - 2338-5413 (P) | Volume 8 No. 1 | Mei 2020 GEDUNG Q FAKULTAS HUKUM UNIVERSITAS PANCASAKTI TEGAL Jl. Halmahera Km. 01, Kota Tegal | Telepon: (0283) 358745 Website: www.diktum.upstegal.ac.id | email: diktum@upstegal.ac.id

keadilan. Untuk itu, hal-hal dibawah ini dapat segera diagendakan sebagai agenda utama reformasi hukum : ${ }^{6}$

1. Menciptakan system hukum yang berisi peraturan yang mengikat semua pihak dan materinya tidak boleh berubah-ubah sesuai keinginan yang bersifat arbiter pemerintah

2. Menjamin kemandirian peradilan untuk mencegah dipakainya hukum sebagai kedok menutupi itervensi kekuasaan yang berlebihan

3. Menjadikan proses legislasi sebagai proses public untuk menghindari penerimaan semu masyarakat terhadap hukum

4. Mengusahakan penegakan hukum secara adil untuk semua orang untuk mencegah timbulnya keberantakan sosial (social disintegration) dan nihilism sosial menyebar tak terkendali

5. System hukum dan penegakannya diorientasikan menjadi mekanisme pengintegrasian sosial dan tidak sekedar legitimasi institusional yang lepas dari persoalan diterima tidaknya oleh masyarakat.

Supremasi hukum merupakan prasyarat mutlak bagi penyelenggaraan kehidupan bernegara berdasarkan kedaulatan rakyat . Supremasi hukum berarti adanya jaminan konstitusional bahwa pelaksanaan dan penegakan hukum dalam proses politik yang dijalankan oleh kekuasaan baik eksekutif, legislatif maupun yudikatif, penyelenggaraan pemerintahan bertumpu pada prinsip kedaulatan rakyat mutlak . Dalam praktek penegakan supremasi hukum dan pelaksanaan demokrasi, pada umumnya aspek kultural sering tertinggal atau sering tidak selaras dengan kualitas aspek substansi. Ketidakserasian aspek struktural dan internal dalam menjalankan demokrasi dan penegakan supremasi hukum dapat berdampak pada meletup dan

\footnotetext{
${ }^{6}$ Martina Oscar, Catatan Terhadap Mengubah Cara-cara Penyelesaian Hukum Oleh Satjipto Rahardjo Melalui Hukum dan Keadilan Dari Hans Kelsen,Wajag Hukum Di Era Reformasi, Menyambut 70 Tahun. Bandung: PT Citra Aditya Bakti, 2000, hlm 62.
} 
berkembangnya konflik politik dan sosial yang kontra produktif. Diperlukan kemampuan melakukan management konflik bagi para wakil rakyat sehingga lembaga politik diperlukan agar konflik dalam masyarakat dapat berfungsi sebagai energy yang dinamis untuk pendewasaan kehidupan demokrasi melalui penegakan yang konsisten. Dalam penegakan supremasi hukum di Indonesia, perlu adanya tatanan hukum yang baik guna menegakkan hukum demi keadilan dan kesetaraan di mata hukum sesuai dengan undangundang. Yang melibatkan semua elemen seperti pemerintah, penegak hukum, masyarakat. $^{7}$

\section{D.Simpulan}

Supremasi hukum merupakan prasyarat mutlak bagi penyelenggaraan kehidupan bernegara berdasarkan kedaulatan rakyat . Supremasi hukum berarti adanya jaminan konstitusional bahwa pelaksanaan dan penegakan hukum dalam proses politik yang dijalankan oleh kekuasaan baik eksekutif, legislatif maupun yudikatif, penyelenggaraan pemerintahan bertumpu pada prinsip kedaulatan rakyat mutlak. Untuk mencapai supremasi yang ideal maka diperlukan penegakan hukum yaitu diarahkan pada pola pencegahan segala pelanggaran hukum baik yang dilakukan oleh individu dalam masyarakat maupun badan hukum.

\section{Daftar Pustaka}

\section{Buku :}

Hakim, Abdul Nusantara, Kebijakan dan Strategi Pembangunan Hukum di Indonesia, Sebuah Tinjauan Kritis politik Pembinaan Hukum Indonesia, dalam buku Pembangunan Hukum dalam Perspektif Politik Hukum Nasional, Jakarta: CV Rajawali, 2000.

\footnotetext{
7Imawan Suiharto, Peran Advokat dalam Upaya Membangun Penegakan Hukum yang Bermartabat, Jurnal Diktum, Tahun 2019 Volume 7 (1). hlm 20.
} 
Martina Oscar,Catatan Terhadap Mengubah Cara-cara Penyelesaian Hukum Oleh Satjipto Rahardjo Melalui Hukum dan Keadilan Dari Hans Kelsen,Wajag Hukum Di Era Reformasi, Menyambut 70 Tahun. Bandung: PT Citra Aditya Bakti, 2000.

Wibisono, Koento Siswomihardjo, Wajah Hukum di Era Reformasi, Menyambut 70 Tahun Satjipto Rahardjo, Bandung: Citra Aditya Bakti, 2000.

Wignyosoebroto, Soetandyo,Hukum Paradigma, Metode dan Dinamika Masalahnya, Jakarta: Huma. 2002.

\section{Jurnal :}

Setiadi. Wicipto, Pembangunan Hukum Dalam Rangka Meningkatkan Supremasi Hukum. Jurnal Rechts Vinding, Volume 1 Nomor 1, April 2012.

Imawan Suiharto, Peran Advokat dalam Upaya Membangun Penegakan Hukum yang Bermartabat, Jurnal Diktum, Volume 7 (1) 2019. 